\title{
PEMBELAJARAN AKTIF, KREATIF, EFEKTIF, DAN MENYENANGKAN UNTUK SISWA SISWI SMK MIGAS CIBINONG
}

\author{
Muhammad Taufiq Fathaddin ${ }^{1 *}$, Ratnayu Sitaresmi ${ }^{2}$, Sugiatmo Kasmungin ${ }^{3}$, M.G. Sriwahyuni ${ }^{4}$, \\ Harin Widyatni ${ }^{5}$, Hari Karyadi Oetomo ${ }^{6}$, Dharmasetiawan ${ }^{7}$ \\ $1,2,3,4,5,6,7$ Universitas Trisakti \\ *E-mail: muh.taufiq@ trisakti.ac.id
}

\begin{abstract}
ABSTRAK
Tujuan akhir dari proses pembelajaran adalah untuk membentuk manusia yang berkualitas tinggi. Metodemetode pembelajaran dikembangkan bukan saja untuk mencapai pemahaman yang lebih baik namun juga untuk meningkatkan perkembangan intelektual, kemampuan bekerja sama, keingintahuan, berpikir secara sistematis. Untuk mencapai hal tersebut, dilakukan penerapan Metode PAKEM di SMK Migas Cibinong, dengan penyuluhan dan pelatihan menggunakan Metode Eksperimen. Penerapan metoda eksperimen ini berguna untuk dapat melihat kemampuan, keterampilan, dan keuletan masing-masing peserta. Pelatihan yang dilakukan menyebabkan siswa lebih aktif dan bersemangat dalam menyelesaikan tugasnya.
\end{abstract}

Kata kunci: metode eksperimen; inkuiri; pembelajaran

\section{ACTIVE, CREATIVE, EFFECTIVE, AND FUN LEARNING FOR STUDENTS OF SMK MIGAS CIBINONG}

\begin{abstract}
The ultimate goal of the learning process is to form high quality human beings. Learning methods are developed not only to achieve a better understanding but also to enhance intellectual development, the ability to work together, curiosity, think systematically. In order to achieve this, the PAKEM Method was implemented at the SMK Migas Cibinong, with counseling and training using the Experimental Method. The application of this experimental method is useful for being able to see the abilities, skills, and tenacity of each participant. The training conducted causes students to be more active and enthusiastic in completing their assignments.
\end{abstract}

Keywords: Experimental Method; Inquiry; Learning

\section{PENDAHULUAN}

Salah satu tujuan pembelajaran dan pendidikan adalah menumbuhkan kemampuan berpikir kritis melalui pelaksanaan tugas-tugas pembelajaran (Hidayatullah, 2011). Oleh karena itu, pembelajaran metode PAKEM (Pembelajaran Aktif, Kreatif, Efektif, dan Menyenangkan ) berbasis inkuiri sangat dianjurkan untuk digunakan dalam pembelajaran di kelas. Pendekatan inkuiri melahirkan interaksi antara yang diyakini siswa sebelumnya terhadap suatu bukti baru untuk mencapai pemahaman yang lebih baik, melalui proses dan metode eksplorasi untuk menguji gagasan-gagasan baru (Wenno, 2008). Inkuiri merupakan proses pembelajaran didasarkan pada pencarian dan penemuan melalui proses berpikir secara sistematis (Sanjaya, 2008). Pengalaman yang diperoleh dari proses pembelajaran perlu dikembangkan untuk membentuk manusia yang berkualitas tinggi (Mulyasa, 2006).

Untuk dapat melaksanakan pembelajaran berbasis inkuiri dengan baik guru harus memperhatikan prinsip-prinsip pelaksanaan pembelajaran ini. Adapun prinsip-prinsip yang dimaksud adalah sebagai berikut:

1. Orientasi Perkembangan Intelektual Siswa

Pembelajaran berbasis inkuiri dirancang oleh para ahli pendidikan dengan tujuan agar dapat meningkatkan perkembangan intelektual anak (siswa). Oleh karena, selama pembelajaran dilangsungkan dengan model pembelajaran berbasis inkuiri ini, proses pembelajaran yang dilakukan oleh anak sangat penting, tidak melulu hanya memperhatikan hasil belajarnya saja. 
BAKTI BANUA : Jurnal Pengabdian Kepada Masyarakat

Volume 1 No. 2 November 2020

e-ISSN : 2722-3736

p-ISSN : 2722-7529

https://ejurnal.stimi-bjm.ac.id/index.php/BBJM/

2. Prinsip Interaksi dan Kolaborasi

Melalui pembelajaran berbasis inkuiri, siswa didorong untuk selalu berinteraksi dengan semua siswa lainnya melalui diskusi-diskusi. Guru menjadi fasilitator dalam pembelajaran. Guru harus mampu membuat siswa termotivasi untuk berkolaborasi dengan teman-teman di dalam kelompoknya, juga dengan teman-teman lain di kelasnya untuk mencapai tujuan pembelajaran yang dikehendaki.

3. Bertanya

Di dalam proses pembelajaran berbasis inkuiri, pertanyaan-pertanyaan yang dilontarkan oleh guru sebagai fasilitator belajar sangat penting. Pertanyaan-pertanyaan diarahkan sehingga siswa terpacu untuk berpikir dan mengembangkan kemampuan kognitifnya. Sedemikian penting pertanyaan yang dilontarkan oleh guru, jauh lebih penting lagi pertanyaan-pertanyaan yang dilontarkan oleh siswa. Pertanyaan-pertanyaan yang dilontarkan oleh siswa menunjukkan seberapa dalam mereka berpikir. Makin baik kualitas pertanyaan-pertanyaan yang dilontarkan siswa, maka makin bagus pembelajaran berbasis inkuiri yang dilaksanakan oleh guru. Pertanyaanpertanyaan ini kemudian harus dicari sendiri oleh siswa pemecahan dan jawabannya. Karena, pembelajaran berbasis inkuri adalah pembelajaran yang membantu siswa mengembangkan sendiri pengetahuannya berdasarkan rasa ingin tahunya.

4. Belajar dalam Pembelajaran Berbasis Inkuri adalah Belajar Berpikir

Prinsip penting pembelajaran berbasis inkuiri adalah belajar berpikir. Ketika siswa diberi rangsangan atau stimulasi di awal pembelajaran, maka akan muncul rasa ingin tahu pada diri mereka. Ini menunjukkan bahwa mereka berpikir. Ketika mereka melontarkan pertanyaanpertanyaan, itu menunjukkan bahwa mereka memiliki rasa ingin tahu, dan juga berpikir. Selanjutnya guru tinggal mengarahkan mereka untuk memuaskan rasa ingin tahu dan melanjutkan proses berpikir tersebut sehingga mereka secara mandiri dan atas dasar keinginan sendiri menemukan pengetahuan dan fakta-fakta yang relevan.

5. Keterbukaan dan Kesempatan Seluas-luasnya untuk Siswa Belajar

Pembelajaran berbasis inkuiri menekankan bahwa peran guru adalah fasilitator di kelasnya. Guru bukan satu-satunya sumber informasi dan juga bukan sumber informasi utama. Informasi dan pengetahuan akan diperoleh siswa dari kesempatan yang diberikan oleh guru untuk mengeksplorasi hal yang ingin diketahui lebih dalam oleh siswa. Adanya keterbukaan bagaimana cara siswa menemukan dan di mana ia menemukan informasi yang dibutuhkan adalah juga merupakan prinsip penting dalam pembelajaran berbasis inkuiri ini. Setiap kelompok-kelompok siswa mungkin akan menggunakan cara-cara dan metode-metode, serta sumber informasi yang berbeda selama proses pembelajarannya.

Kegiatan pengabdian kepada masyarakat dilakukan di di SMK Migas Cibinong, Bogor, Jawa Barat. Melalui kegiatan ini, tim memberikan penyuluhan kepada para guru dan murid tentang Metoda PAKEM. Lebih lanjut, simulasi penerapan Metoda PAKEM dilakukan untuk melihat pengaruh metoda ini pada proses kegiatan belajar mengajar.

\section{KAJIAN TEORITIS}

Pembelajaran merupakan sebuah proses yang mengandung serangkaian perbuatan guru dan siswa atas dasar hubungan timbal balik, yang berlangsung dalam situasi edukatif untuk mencapai tujuan tertentu (Djamarah, 2000; Usman, 2000). Proses pembelajaran merupakan interaksi semua komponen atau unsur yang terdapat dalam pembelajaran, yang satu sama lainnya saling berhubungan dalam sebuah rangkaian untuk mencapai tujuan. Adapun yang termasuk dalam komponen pembelajaran adalah tujuan, bahan, metode, alat, dan penilaian (Sudjana, 1989). Metode Pembelajaran Interaktif, dapat dilakukan dengan berbagai cara, diantaranya: Metode Ceramah, Metode Proyek, Metode Eksperimen, Metode Pemberian Tugas dan Pembacaan, Metode Diskusi, dan Metode Latihan.

Metode Ceramah mempunyai kelebihan dan kekurangan. Kelebihan metode ceramah diantaranya: guru mudah menguasai kelas, mudah dilaksanakan, dapat diikuti siswa dalam jumlah 
BAKTI BANUA : Jurnal Pengabdian Kepada Masyarakat

Volume 1 No. 2 November 2020

e-ISSN : 2722-3736

p-ISSN : 2722-7529

https://ejurnal.stimi-bjm.ac.id/index.php/BBJM/

besar, dan guru mudah menerangkan banyak bahan pelajaran. Adapun kelemahannya adalah sebagai berikut. Siswa yang lebih tanggap dari sisi visual akan merasa dirugikan, sedangkan siswa yang lebih tanggap terhadap kemampuan auditifnya, akan mendapatkan manfaat lebih besar. Pelaksanaan metode ceramah yang terlalu lama akan membuat siswa merasa bosan. Di samping itu, sukar untuk mengontrol sejauh mana pemerolehan belajar siswa dan juga menyebabkan siswa menjadi pasif

Metode Proyek adalah suatu cara mengajar yang memberikan kesempatan untuk menggunakan unit kehidupan sehari-hari sebagai bahan pembelajaran. Kelebihan metode proyek adalah dapat merombak pola pikir siswa dari yang sempit menjadi luas dan menyeluruh, ketika memandang dan memecahkan masalah yang dihadapi dalam kehidupan. Melalui metode ini, siswa dibina untuk membiasakan diri menerapkan pengetahuan, sikap, dan ketrampilan secara terpadu, sehingga diharapkan bisa berguna dan dipraktikan dalam kehidupan sehari-hari.

Metode Eksperimen adalah metode pemberian kesempatan kepada siswa, baik secara perorangan atau kelompok, untuk dilatih melakukan suatu proses atau percobaan. Dengan metode ini diharapkan ia bisa sepenuhnya terlibat dalam merencanakan dan melakukan eksperimen, menemukan fakta, mengumpulkan data, mengendalikan variabel, dan memecahkan masalah yang dihadapinya secara nyata. Kelebihan metode eksperimen adalah dapat membuat siswa lebih percaya atas kebenaran atau kesimpulan berdasarkan percobaannya sendiri daripada hanya menerima kata dari guru atau buku. Metode eksperimen dapat mengembangkan sikap untuk mengadakan studi eksplorasi (ilmu) dan teknologi, suatu sikap yang dituntut dari seorang ilmuwan. Dengan metode ini, akan terbina manusia yang dapat membawa terobosan-terobosan baru. Sedangkan kelemahan metode eksperimen adalah alat-alat atau sarana untuk bereksperimen harus mencukupi jumlahnya, sehingga setiap siswa dapat berkesempatan untuk mengadakan eksperimen dalam waktu yang bersamaan. Jika eksperimen memerlukan jangka waktu yang lama, maka siswa harus menanti untuk melihat hasil ekperimennya. Metode ini lebih sesuai untuk menyajikan bidang-bidang ilmu dan teknologi.

Metode Pemberian Tugas dan Pembacaan (Recitation) dilakukan dimana guru memberi tugas kepada siswa dan mengaitkannya dengan tugas-tugas lainnya, seperti mencari dan membaca buku lain sebagai perbandingan, atau disuruh melakukan pengamatan pada lingkungannya setelah membaca buku tersebut tanpa terikat tempat. Kelebihan metode ini adalah memungkinkan pengetahuan yang siswa peroleh dari hasil belajar sendiri akan dapat diingat lebih lama. Di samping itu siswa berkesempatan untuk memupuk perkembangan dan keberanian dalam mengambil inisiatif, bertanggung jawab, dan berdiri sendiri. Sedangkan kelemahan metode ini adalah seringkali siswa melakukan peniruan hasil pekerjaan orang lain tanpa mau bersusah payah mengerjakan sendiri. Tambahan pula bisa jadi siswa yang diberi tugas meminta orang lain untuk mengerjakannya tanpa mau bersusah payah mengerjakan sendiri.

Metode Diskusi adalah metode dengan cara membahas suatu persoalan dengan melibatkan banyak orang, dimana hasil dari pembahasan tersebut akan menjadi alternatif jawaban dalam memecahkan persoalan. Dalam kaitan ini, orang-orang yang terlibat di dalamnya mengemukakan pandangannya sendiri-sendiri terhadap persoalan yang dilontarkan. Selanjutnya, berbagai pandangan tersebut dianalisis dan dicari pandangan yang paling ideal dan mewakili semua peserta.

Kelebihan metode diskusi adalah dapat menyadarkan siswa bahwa masalah dapat dipecahkan dengan berbagai jalan dan bukan satu jalan (satu jawaban saja). Di samping itu metode ini dapat menyadarkan para siswa bahwa dengan berdiskusi, mereka bisa saling mengemukakan pendapat secara konstruktif, sehingga dapat diperoleh keputusan yang lebih baik. Kelebiha lainnya adalah membiasakan siswa untuk mendengarkan pendapat orang lain, sekalipun berbeda dengan pendapatnya sendiri dan membiasakan bersikap toleran. Sedangkan kelemahan metode diskusi ini dintaranya adalah tidak dapat dipakai pada kelompok yang besar, peserta diskusi mendapat informasi yang terbatas, dapat dikuasai oleh orang-orang yang suka berbicara, dan biasanya orang menghendaki pendekatan yang lebih formal.

Metode latihan atau drill, juga biasa disebut dengan metode training. Metode ini merupakan metode yang digunakan guru untuk mengajar dalam upaya menanamkan berbagai kebiasaan atau keterampilan tertentu kepada para siswa. Dengan begitu, mereka akan menguasai keterampilan atau 
BAKTI BANUA : Jurnal Pengabdian Kepada Masyarakat

Volume 1 No. 2 November 2020

e-ISSN : 2722-3736

p-ISSN : 2722-7529

https://ejurnal.stimi-bjm.ac.id/index.php/BBJM/

kebiasaan baru, sehingga dapat dijadikan bekal dalam kehidupan mereka kelak. Kelebihan metode latihan adalah siswa dapat memperoleh kecakapan motoris, seperti menulis, melafalkan huruf, membuat dan menggunakan alat-alat. Siswa dapat memperoleh kecakapan mental misalnya dalam perkalian, penjumlahan, pengurangan, pembagian, tanda-tanda/simbol, dan lain sebagainya. Di samping itu, siswa dapat membentuk kebiasaan dan menambah ketepatan ataupun kecepatan dalam pelaksanaan. Kelemahan metode latihan adalah berpotensi menghambat bakat dan inisiatif siswa, karena ia lebih banyak dibawa pada penyesuaian dan diarahkan jauh dari pengertian. Selain itu metode ini dapat menimbulkan penyesuaian secara statis pada lingkungan. Lebih lanjut, terkadang latihan yang dilaksanakan secara berulang-ulang merupakan hal yang monoton dan membosankan.

\section{METODE}

Pengabdian Kepada Masyarakat dilakukan untuk mensosialisasikan Metoda PAKEM (Pembelajaran Aktif, Kreatif, Efektif, dan Menyenangkan) meningkatkan kualitas belajar dan mengajar di SMK Migas Cibinong, Bogor. Sosialisasi dilakukan dengan ceramah dan pelatihan tentang Metoda PAKEM. Adapun sasaran penyuluhan adalah para siswa kelas 11. Melalui kegiatan pengabdian kepada masyarakat ini, metode yang dilakukan yaitu:

o Penyuluhan Metode Pakem yang meliputi Metode Ceramah, Metode Proyek, Metode Eksperimen, Metode Pemberian Tugas dan Pembacaan, Metode Diskusi, dan Metode Latihan (Gambar 1)

o Praktek penerapan salah satu Metode Pakem yaitu Metode Eksperimen (Gambar 2).

\section{HASIL DAN PEMBAHASAN}

Kegiatan PKM dibagi ke dalam dua sesi. Sesi pertama adalah penyampaian materi Metoda PAKEM (Pembelajaran Aktif, Kreatif, Efektif, dan Menyenangkan) sebagaimana diberikan pada Bab II. Pada sesi kedua dilakukan pelatihan/simulasi pelaksanaan Metoda PAKEM dengan menggunakan Metode Eksperimen. Dalam simulasi ini setiap peserta diberi alat praktek berupa delapan buah sedotan, lilin (malam), pensil, penggaris, dan selotip. Dengan peralatan tersebut peserta diminta untuk membuat seruling dengan nada yang berbeda (do, re, mi, fa, sol, la, si, dan do).

Dengan metode setiap peserta sepenuhnya bebas merencanakan dan melakukan eksperimen. Ada beberapa pembelajaran dalam pembuatan seruling seperti: bagaimana fungsi masing-masing bahan dan tinggi rendahnya nada yang terbentuk tergantuk dari posisi penyumbat (lilin/malam). Penentuan jarak penyumbat untuk menghasilkan nada (do, re, mi, fa, sol, la, si, dan do). Dilakukan dengan coba-coba. Semakin dekat jarak penyumbat frekuensi nada semakin tinggi. Kelemahan simulasi dengan metode eksperimen adalah kurangnya waktu, karena tidk semua peserta dapat menyelesaikan pembuatan kedelapan suling tersebut dengan suara yang diinginkan.

\section{SIMPULAN}

Kegiatan PKM dalam penyuluhan dan diskusi tentang Penerapan Metoda PAKEM di SMK Migas Cibinong, Bogor di mana dosen-dosen Jurusan Teknik Perminyakan Fakultas Teknologi Kebumian dan Energi bertindak sebagai penyuluh sangat bermanfaat sebagai upaya untuk meningkatkan kualitas belajar mengajar. Penerapan metoda eksperimen ini berguna untuk dapat melihat kemampuan, keterampilan, dan keuletan masing-masing peserta. Pelatihan yang dilakukan menyebabkan siswa lebih aktif dan bersemangat, namun kelemahan metoda ekperimen ini adalah membutuhkan waktu yang lebih banyak agar setiap siswa dapat menyelesaikan tugasnya.

\section{UCAPAN TERIMAKASIH}

Penulis mengucapkan terimakasih kepada Kepala Sekolah dan guru-guru di SMK Migas Cibinong, Bogor atas kerjasama yang telah terjalin serta kesempatan untuk melaksanakan kegiatan pengabdian kepada para siswa dan siswi. 
BAKTI BANUA : Jurnal Pengabdian Kepada Masyarakat

Volume 1 No. 2 November 2020

e-ISSN : 2722-3736

p-ISSN : 2722-7529

https://ejurnal.stimi-bjm.ac.id/index.php/BBJM/

\section{DAFTAR PUSTAKA}

Djamarah, S. B. 2000. Guru dan Anak Didik dalam Interaksi Edukatif. Jakarta: Rineka Cipta.

Hidayatullah, F. M. 2011. Menjadi Guru Sejati. Seminar Nasional Himpunan Mahasiswa Pendidikan Biologi , FKIP, Universitas Sebelas Maret, 19 Maret.

Mulyasa, E. 2005. Kurikulum Berbasis Kompetensi Konsep, Karakteristik, Dan Implementasi. Bandung: PT. Remaja Rosdakarya.

Sanjaya, W. 2008. Pembelajaran Dalam Implementasi Kurikulum Berbasis Kompetensi. Jakarta: Prenata Media Group.

Sudjana, N. dan Ibrahim. 1989. Penelitian dan Penilaian Pendidikan. Bandung: Sinar Baru.

Usman, Moh. Uzer, “Menjadi Guru Profesional”, Remaja Rosdakarya, Bandung, 2000.

Wenno, I. H. 2008. Strategi Belajar-Mengajar Sains Berbasis Konstektual. Yogyakarta: Inti Media.

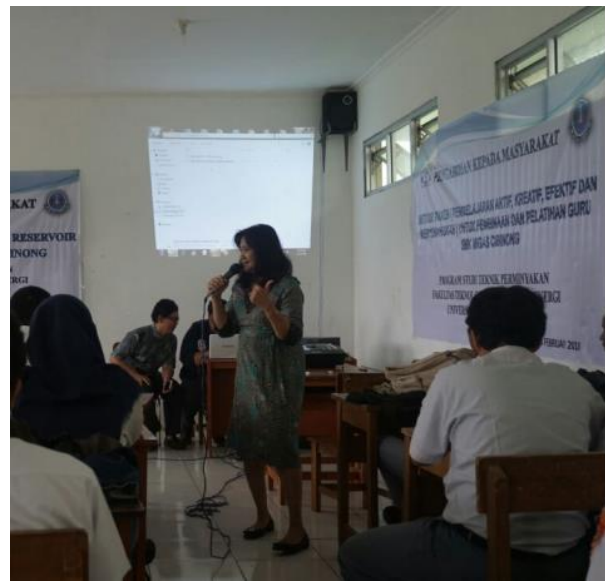

Gambar 1. Sosialisasi Metode PAKEM

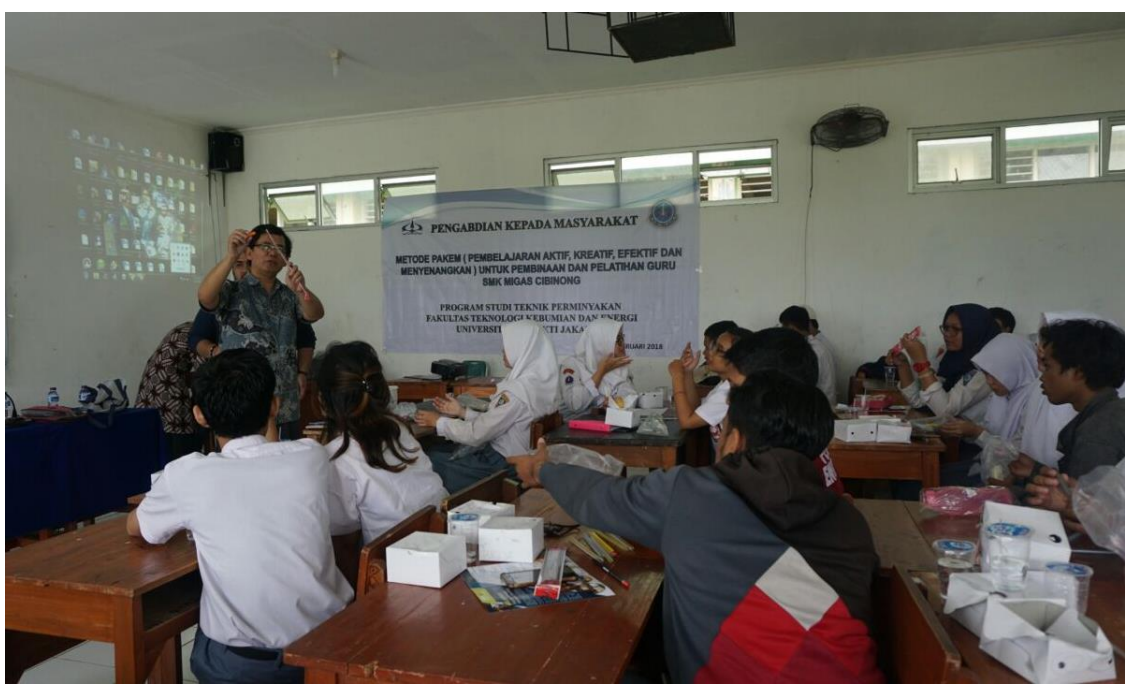

Gambar 2. Penerapan Metode Eksperimen 